Journal of Animal \& Plant Sciences, 31(5): 2021, Page: 1520-1529

ISSN (print): 1018-7081; ISSN (online): 2309-8694

https://doi.org/10.36899/JAPS.2021.5.0354

\title{
PRELIMINARY PHYTOCHEMICAL ANALYSIS AND BIOLOGICAL EVALUATIONS OF MISOPATES ORONTIUM L.
}

\author{
S. Akbar and S. Ishtiaq* \\ Punjab University College of Pharmacy, University of the Punjab, Lahore, Pakistan \\ *Corresponding Author's email: dr.shehla333@gmail.com
}

\begin{abstract}
Misopates orontium L. is traditionally used as diuretic, in liver disorders and also in treatment of ulcer. The objective of present study to evaluate anthelmintic, insecticidal and anti-ulcer potential of $M$. orontium. Albendazole $(20 \mathrm{mg} / \mathrm{ml}) \mathrm{was}$ used as standard drug in anthelmintic activity. Permethrin $\left(239.5 \mu \mathrm{g} / \mathrm{cm}^{2}\right)$ was used as standard insecticidal drug. While standard drugs used for anti-ulcer activity were ranitidine $(50 \mathrm{mg} / \mathrm{kg})$, omeprazole $(20 \mathrm{mg} / \mathrm{kg})$ and sucralfate $(100 \mathrm{mg} / \mathrm{kg})$. In anthelmintic activity ethyl acetate and $\mathrm{n}$ - butanol fraction showed time of paralysis $(59 \mathrm{~min}),(57 \mathrm{~min})$ and death time (107min), (114min) respectively. No extract showed any significant insecticidal activity. Ulcer indices, percentage ulcer inhibition, gastric volume, $\mathrm{pH}$, mucous and protein contents were assessed in ethanol induced ulcer model in rats. Chloroform extract of $M$. orontium significantly reduced gastric lesion $39.84 \%$ at $50 \mathrm{mg} / \mathrm{kg}$ when compared to ranitidine $(54.2 \%)$, omeprazole $20 \mathrm{mg} / \mathrm{kg}(69.5 \%)$ and sucralfate $100 \mathrm{mg} / \mathrm{kg}(53.6 \%)$. Gastric volume and total acidity decreased $(1.87 \pm 0.2)(45.5 \pm 5.9)$ in chloroform treated group. While $\mathrm{pH}$, mucous and protein content increased in comparison to ethanol treated group (5.1 \pm 0.3$),(478.3 \pm 12.7),(26.1 \pm 4.1)$ and $(2.4 \pm 0.1),(371.8 \pm 10.2),(16.2 \pm 3.2)$ respectively. Chloroform treated group all values are close relevant to standard drug treated groups. So it was concluded that chloroform extract showed more safe result as compared to other extracts.
\end{abstract}

Keywords: Misopates orontium; gastric lesion; anthelmintic; insecticidal; phytochemical; antioxidant.

Published first online January 21, 2021 Published Final August 07, 2021.

\section{INTRODUCTION}

In the early age human being throughout the world is suffering from various kinds of infections which cause a large number of diseases. To overcome such diseases various strategies are being in process. Among them medicinal plants play crucial role in care the improvement of human health (Bruneton, 1955). In this regard ethno medical knowledge of traditional medicinal plants and their pharmacological screening are in practice in various regions of Pakistan (Khan et al., 2016). Medicinal plant contains a large number of antioxidants compounds which are used for the prevention of oxidative stress. For this purpose, in the present study, it is decided to add the antioxidants in suitable amount in the food as an additive, in cosmetics and in pharmaceutical products (Sahreen et al., 2015). According to different reports it was shown that various parts of medicinal plants viz; fruits, leaves, stem, roots and vegetables have free radical scavenging and microbial growth control efficacy (Rababah et al., 2004) which may be used as natural antioxidants and for the treatment of various diseases (Sahreen et al., 2014). Pakistan has blessed with large number of medicinal plants rich in ethno medicinally important compounds. Those possess activities against various diseases. These plants are being used in preparation of various drugs since decades (Javed et al., 2019; Riaz et al., 2019).
Misopates orontium L. belongs to family Scrophulariaceae. It is an annual herbaceous plant found in hilly areas of Pakistan especially Margallah Hills National Park. The ethno-botanical values of this plant were used as fodder, in medicinal preparations, as fiber, as fuel wood, as timber, in tanning industry and in preparation of gum (Jabeen et al., 2009). M. orontium is claimed to be used for a number of therapeutic assiduities such as, it has bitter and stimulant properties, the whole plant has been employed for the treatment of tumors and ulcers. The scientific approval and the mechanisms of such claims are lacking in the literature (Lönnig et al., 2007).

Parasitism is of supreme importance in many agro-ecological zones of Pakistan. Infection caused by helminthes (gastrointestinal nematodes) is most common and more persistent form of infection. Other contributing factors in infection are malnutrition, pneumonia, eosinophilia and anemia which pose a great threat to human health particularly in developing countries (Bundy, 1994). These parasites and their larvae are passing through human intestinal tract by eating contaminated food and also subsist into their body tissues (Tripathi, 2003). Development of resistance is one of the major problems in treatment of helminths (Tagboto and Townson, 2001; Sondhi et al., 2000). A Sustainable control strategy complemented with effective anthelmintics and selective breeding for enhanced resistance are desirable for parasite control (Coles et al., 2006). 
Gastrointestinal infection is one of the major complication worlds widely. These infections cause peptic ulcer, rate of morbidity is high due to these infections (Tanih et al., 2010). Even though various famous antiulcer drugs are available in the market, various toxicities and adverse effects are also associated to these antiulcer drugs. Thus, there is need to focus on searching of new alternative drugs (Prabhu and Shivani, 2014). Symptoms of ulcer are pain in stomach with burning sensation, episodes of distress, pain after food intake or empty stomach, other common symptoms are vomiting, intolerance to fatty diet and loss of appetite (Ramakrishnan and Salinas, 2007).

Physiologically, reactive oxygen species is usual cause of various illnesses i.e peptic ulcer (Garber and Jang, 2016). The safest treatment is the use of natural antioxidants which are responsible to react with free oxygen specie to reduce the consequences of illness. Misopates has antioxidant activity which is proved by literature (Riaz et al., 2013) so it is used for gastro protective activity has not been studied yet. The present project was basically designed for the pharmacological evaluation via different assays viz; anthelmintic, insecticidal and antiulcer activity of $M$. orontium $\mathrm{L}$.

\section{MATERIALS AND METHODS}

Collection and extraction: Plant was collected from Bhimber (Bandiala), Kotli, Azad Kashmir and authenticated by Dr. Uzma Hanif, Department of Botany, Government College University (GCU), Lahore, Pakistan, voucher No: GC. Herb. Bot. 3458. Powdered plant material stored in amber colored bottles at dry place. Methanolic extract made by maceration using rotary evaporator under reduced pressure at 45-50 ${ }^{\circ} \mathrm{C}$. Fractionation was performed on crude extract by using nhexane, chloroform, ethyl acetate, n-butanol of increasing order of polarity. Each fraction of these solvents was dried and preserved for different biological evaluation.

Helminths, Insects and Animals: Earthworms collected from crops field of Sialkot, test insects red grain borer, rice weevil, lesser grain borer (Tribolium castaneum, Sitophilus oryzae, and Rhyzopertha dominica) and Wistar albino rats (200-250 gm) were used. Use of animals following the rules set by Institutional Ethical Committee for Animal care and Experimentation is Guideline Document No. 423 provided by Zoology Department, University of the Punjab, Lahore, Pakistan.

Phytochemical analysis: The herb was carried out according to the standard procedures for phytochemical analysis (Ishtiaq et al., 2017).

Total phenolic content: Estimation of total poly phenolic contents in plant sample was done according to Liaudanskas (Liaudanskas et al., 2017). Gallic acid was used as a standard.
Total Flavonoid content: Flavonoid determination was done by Ejikeme et al., 2014 and Boham and Kocipai, 1994 method. The percentage of flavonoid was calculated.

$\mathbf{Y}=\mathbf{1 . 0 2 5 X}+\mathbf{0 . 1 9 5}, \mathbf{R}_{\mathbf{2}}=\mathbf{0 . 9 9 8 4}$ for polyphenol standard Gallic acid.

$\mathbf{Y}=\mathbf{0 . 0 0 0 8 X}+\mathbf{0 . 0 4 8 3}, \mathbf{R}_{\mathbf{2}}=\mathbf{0 . 9 9 6 9}$ for flavonoid standard is quercetin.

In these standard curves where $y$ is absorbance at $760 \mathrm{~nm}$ and $\mathrm{x}$ is total phenolic/ flavonoid content in the different extracts. $\mathrm{R}_{2}$ values represented mean data set of $\mathrm{n}=3$. It is linear regression coefficient $\left(\mathrm{R}_{2}\right)$ for phenolic and flavonoid content with antioxidant activity.

Acute toxicity: Preliminary experiments were carried out in mice $(n=6)$. Methanolic extract of Misopates orontium L. was administered in doses (500, 1000 and 2000 $\mathrm{mg} / \mathrm{kg} / \mathrm{p} . \mathrm{o}$ ) to find out toxicity which cause zero and 100 $\%$ mortality of animals. It was conducted by OECD guideline (Guideline Document No. 423). Animal ethical committee of Zoology Department of the Punjab University provided this number 416 for authentication of animals use in this research project according to ethical guidelines.

Anthelmintic activity: Ajaiyeoba et al., 2001 method followed for it. The experimental procedure carried on adult earth worm which are anatomically and physiologically resemble to human intestinal worms. These earthworms divided into groups of six and put into each petri dishes containing three different concentration $(25,75,100 \mathrm{mg} / \mathrm{ml})$ of all fractions of extract of whole herb M. orontium L. Albendazole $(20 \mathrm{mg} / \mathrm{ml})$ was used as standard drug. Then note the time of paralysis or any physiological change and mortality.

Insecticidal activity: For insecticidal activity impregnated filter paper method was followed (Choudhary and Thomsen, 2001). In this method 10 healthy and active insects put on filter paper which was placed in Petri dish. Filter paper impregnated in sample, each Petri dish left for $24 \mathrm{hrs}$. Incubate them at 50\% relative humidity in growth chamber. Count the number of survival of each specie and calculate percentage of morality. Standard insecticide (permethrin) at conc. $\left(239.5 \mu \mathrm{g} / \mathrm{cm}^{2}\right)$ was used.

Percentage Mortality =

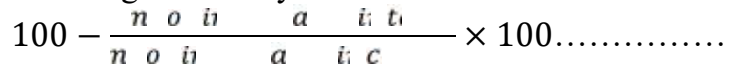




\section{Evaluation of antiulcer activity}

Ethanol induced gastric ulcer model: Wistar albino rats were divided into 11 groups randomly $(n=6)$, followed the method of Mizui et al., 1987. After 24 hours of fasting, animals were allowed free access to water for $2 \mathrm{hr}$ prior to experimental procedure (Alphin and Ward, 1967).

Group 1: served as normal (-ve control) received $5 \mathrm{ml} / \mathrm{kg}$ p.o of distilled water; Group 2: (+ve control) was treated with absolute ethanol 1ml/animal; Group 3: standard treated with ranitidine $(50 \mathrm{mg} / \mathrm{kg}$ p.o); Group 4: omeprazole (20mg/kg p.o); Group 5: sucralfate $(100 \mathrm{mg} / \mathrm{kg}$ p.o); Group 6:(Extract treated) received methanolic extract $500 \mathrm{mg} / \mathrm{kg}$ p.o; Group 7-11 received aqueous, n-hexane, chloroform, ethyl acetate and butanol $200 \mathrm{mg} / \mathrm{kg}$ p.o, followed by $1 \mathrm{ml}$ ethanol respectively (Hollander et al., 1985; Balmik et al., 2019; Zangeneh et al., 2019).

Measurement of ulcer index: Stomachs were examined for hemorrhagic lesion in mucosal lining of stomach (Magaji et al., 2007) then percentage inhibition was calculated by applying formula: \% Gastro protection $/$ Inhibition $=($ UIC - UIT $) /$ UIC X 100

Where UIC is Ulcer Index in the control and UIT is ulcer index in the test rats (Navarrete et al., 1998).

Determination of total acidity: Gastric acidity was determined by method of Shay (Shay, 1945). For this gastric content was collected from the stomach into graduated tubes. These tubes were centrifuged for $15 \mathrm{~min}$ at 2000rpm, supernatant was used for gastric volume, $\mathrm{pH}$ and total acidity by titrating with $0.01 \mathrm{~N} \mathrm{NaOH}$.

Estimation gastric mucus and protein content: Glandular portion of stomach was used for estimation of mucous and protein content (Kamran et al., 2019; Lowry et al., 1951).

Histological analysis of gastric ulcer: Small portion of stomach from each experimental group was fixed in preservative for histopathological studies. Thin sections of $5 \mu$ were cut by using microtome and stained with eosin and hematoxylin. These sections were studied for degenerative features under supervision of Dr. Zahid chief incharge of Histopathological laboratory of King Edward Medical College University, Lahore (Boligon et al., 2014).

Statistical analysis: In anthelmintic and insecticidal activity simple mean and standard deviation (SD) of the data was determined with the help of statistical software SPSS 19. In antiulcer activity one-way analysis variance (ANOVA) was performed followed by Dunnett's t-test for multiple comparisons. The significance of difference was accepted at $p<0.05$. Graphical representation was made by graph prism pad 6 .

\section{RESULTS}

Phytochemical analysis: Results shown in table 1 and 2 . Crude extract indicated presence of all major classes of compounds carbohydrates, alkaloids, glycosides, tannins, flavonoids, triterpenoids etc. all other fractions have different concentration of polyphenols and flavonoids compared with Gallic acid and quercetin respectively.

Anthelmintic activity: Earthworms divided into 22 groups, each fraction (methanol, n-hexane, ethyl acetate, chloroform, n-butanol, aqueous) divided into three concentrations 25,75 and $100 \mathrm{mg} / \mathrm{ml}, \mathrm{n}=6$. The time of paralysis and death in control group is $37.4 \pm 3.4 \mathrm{~min}, 55.2$ $\pm 6.3 \mathrm{~min}$, respectively at $100 \mathrm{mg}$ conc. While ethyl acetate $(53.8 \pm 3.0 \mathrm{~min}, 80.4 \pm 7.2 \mathrm{~min})$ and $\mathrm{n}$ - butanol fractions $(50.2 \pm 3.9 \mathrm{~min}, 86 \pm 8.0 \mathrm{~min})$ showed results comparable to control group at $100 \mathrm{mg} / \mathrm{ml}$. These results given in Figure 1 and 2.

Insecticidal activity: For insecticidal three kinds of insects (Tribolium castaneum, Sitophilus oryzea and Rhyzopertha dominica) at $200 \mathrm{mg} / 3 \mathrm{ml}$ conc. permethrin is standard insecticidal at conc. $\left(239.5 \mu \mathrm{g} / \mathrm{cm}^{2}\right) . \%$ age mortality is calculated by applying formula. Results given in table 3.

Table 1. Preliminary phytochemical analysis of Misopates orontium L.

\begin{tabular}{lll}
\hline $\begin{array}{l}\text { Phytochemical } \\
\text { group }\end{array}$ & Test & $\begin{array}{l}\text { Methanolic } \\
\text { extract }\end{array}$ \\
\hline Terpenoids & $\begin{array}{l}\text { Salkowaski test } \\
\text { Liebermann's test }\end{array}$ & ++ \\
& Ferric Chloride & + \\
Tannins & test & + \\
& Bromine water test & ++ \\
Glycosides & Keller killani test & ++ \\
& Legal 's test & + \\
Flavonoids & Alkaline reagent & ++ \\
& test & ++ \\
& Lead acetate test & +++ \\
Alkaloids & Mayer 'test & +++ \\
& Wagner 'test & +++ \\
Proteins & Hager 's test & +++ \\
& Dragendroff's test & + \\
Carbohydrates & Millon's test & + \\
Saponins & Ninhydrin test & ++ \\
Fats and Fixed & Molisch 's test & ++ \\
oil & Benedicts 's test & +++ \\
\hline
\end{tabular}

Ethanol induced ulcer model: Wistar albino rats were used for ethanol induced ulcer model, ethyl acetate fraction shows maximum \% age inhibition of ulcer. As result shown in Table 4. Gastric volume increased in ethanol treated group (+ve control) while decrease in 
standard drugs treated groups as well as extract treated groups. PH decreased in ethanol treated group, increased in all other groups. Total acidity increased in ethanol treated group, all groups showed decrease in acidity, given in Table 5. Mucous content decreased and protein content increased in ethanol treated group and vice versa in all other treated groups, given in Table 5.

Table 2. Determination of Polyphenols and Flavonoids in various extracts of Misopates orontium $\mathbf{L}$.

\begin{tabular}{lcccc}
\hline \multicolumn{1}{c}{ Parameters } & \multicolumn{2}{c}{ \%Total polyphenols } & \multicolumn{2}{c}{ \% Total flavonoids } \\
\cline { 2 - 4 } Methanol & Mean & SD & Mean & SD \\
n-hexane & 0.909 & \pm 0.006 & 0.088 & \pm 0.003 \\
Chloroform & 0.580 & \pm 0.004 & 0.062 & \pm 0.003 \\
Ethyl acetate & 0.918 & \pm 0.006 & 0.180 & \pm 0.006 \\
n-butanol & 0.920 & \pm 0.005 & 0.220 & \pm 0.004 \\
Aqueous & 0.829 & \pm 0.005 & 0.203 & \pm 0.007 \\
\hline
\end{tabular}

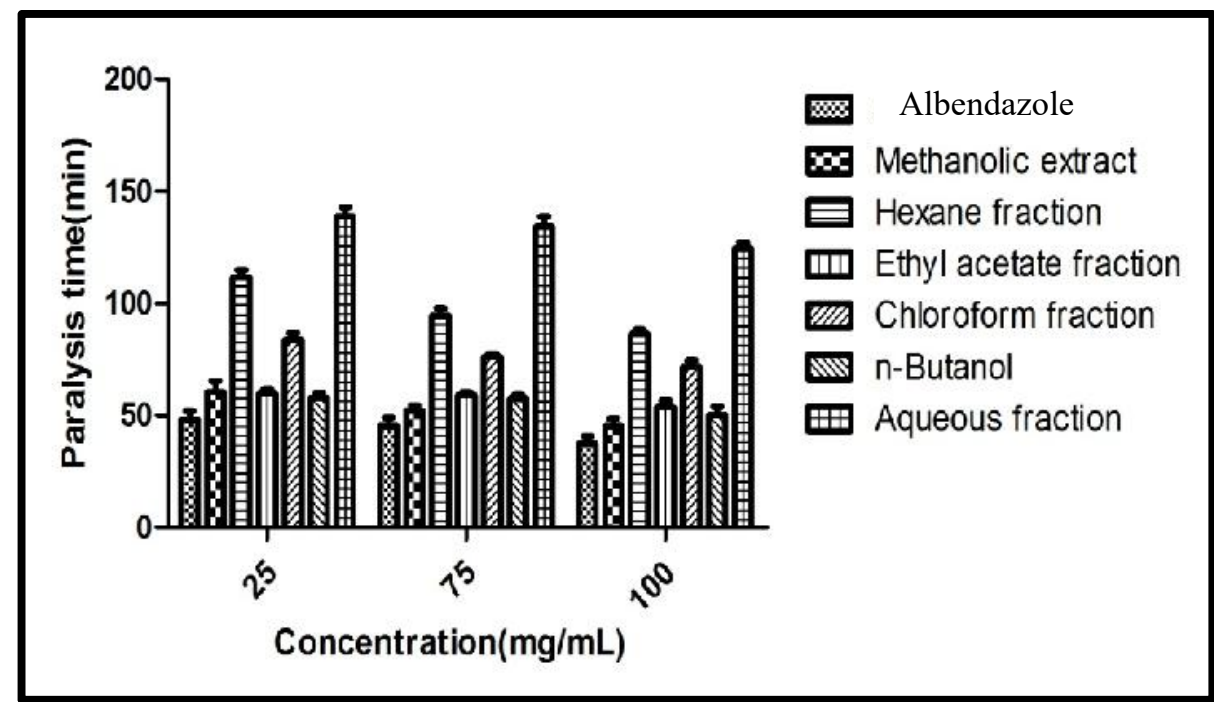

Figure 1. Graphical representation of time of paralysis vs concentartion of different extracts as compared to control standrd drug albendazole.

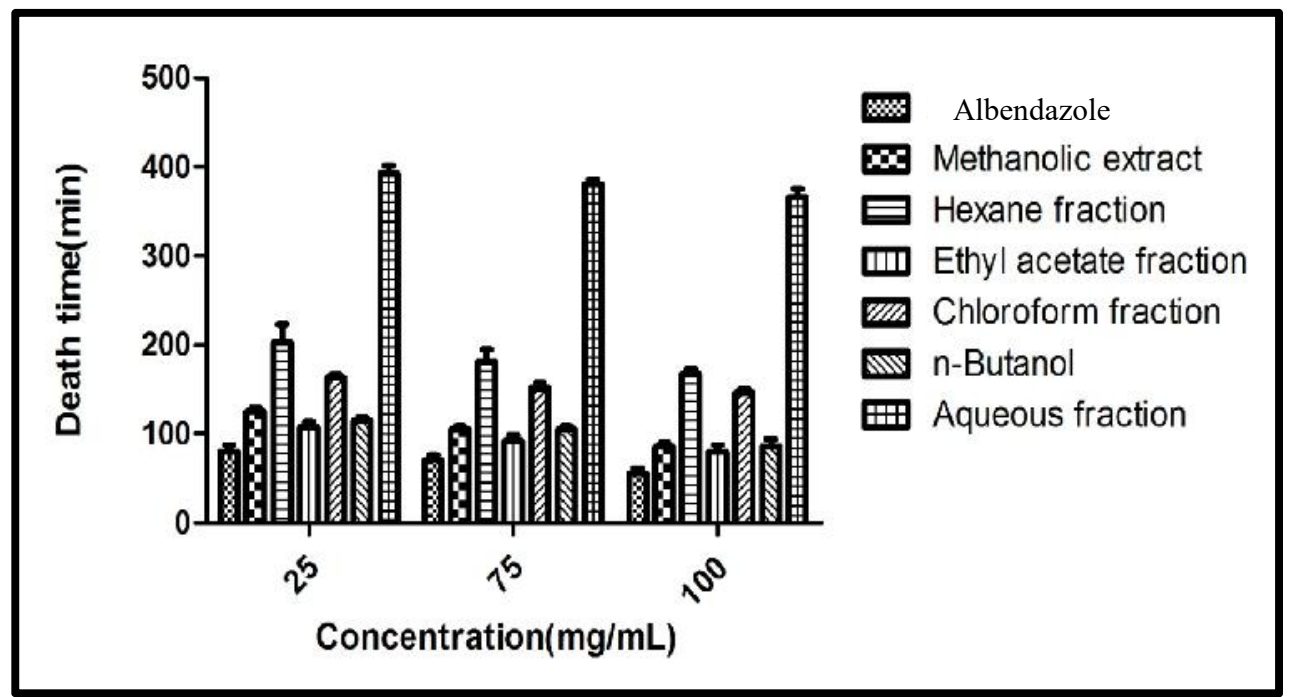

Figure 2. Graphical representation of time of death vs concentartion of different extracts as compared to control standrd drug albendazole. 
Table 3. Insecticidal activity of different fractions of Misopates orontium $\mathbf{L}$.

\begin{tabular}{lccc}
\hline \multicolumn{1}{c}{ Extract/Fraction } & \multicolumn{2}{c}{ Mortality (Mean \pm SD) } \\
\cline { 2 - 4 } & Tribolium castaneum & Sitophylus oryzae & $\begin{array}{c}\text { Rhzopertha } \\
\text { dominica }\end{array}$ \\
-ve Control & 0 & 0 & 0 \\
+ve Control(Permethrin) $(20 \mathrm{mg} / 3 \mathrm{ml})$ & 100 & 100 & 100 \\
Methanol $(200 \mathrm{mg} / 3 \mathrm{ml})$ & 0 & 10 & 0 \\
n-Hexane $(100 \mathrm{mg} / 3 \mathrm{ml})$ & 0 & 0 & 0 \\
Ethyl acetate $(100 \mathrm{mg} / 3 \mathrm{ml})$ & 20 & 20 & 0 \\
Chloroform $(100 \mathrm{mg} / 3 \mathrm{ml})$ & 0 & 0 & 0 \\
Butanol $(100 \mathrm{mg} / 3 \mathrm{ml})$ & 10 & 0 & 0 \\
Aqueous $(100 \mathrm{mg} / 3 \mathrm{ml})$ & 0 & 0 & 0 \\
\hline
\end{tabular}

Results are shown as Mean \pm SEM. Significant at $\mathrm{P}<0.05, \mathrm{P}<0.01, \mathrm{P}<0.001$, ns $=$ not significant

Table 4. Effect of different fraction of M. orontium on ethanol induced gastric ulcer.

\begin{tabular}{lccccc}
\hline \multicolumn{1}{c}{ Group name } & Ulcer no. & Ulcer score & $\begin{array}{c}\text { Incidence of } \\
\text { ulcer (\%) }\end{array}$ & $\begin{array}{c}\text { Ulcer } \\
\text { index }\end{array}$ & $\begin{array}{c}\text { Inhibition of } \\
\text { ulcer (\%) }\end{array}$ \\
\hline Normal (10ml/kg p.o) & $0.00 \pm 0.00^{* * *}$ & $0.00 \pm 0.00^{* * *}$ & 0 & 0 & 0 \\
Ethanol (10ml/kg p.o) & $7.83 \pm 0.60$ & $5.75 \pm 0.57$ & 100 & 11.36 & 0 \\
Ranitidine (50mg/kg p.o) & $1.00 \pm 0.52^{* * *}$ & $1.00 \pm 0.47^{* * *}$ & 50 & 5.2 & 54.22 \\
Omeprazole (20mg/kg p.o) & $0.67 \pm 0.42^{* * *}$ & $0.58 \pm 0.37^{* * *}$ & 33.33 & 3.46 & 69.56 \\
Sucralfate (100mg/kg p.o) & $1.17 \pm 0.54^{* * *}$ & $1.50 \pm 0.67^{* * *}$ & 50 & 5.27 & 53.63 \\
Methanol (500mg/kg p.o) & $2.00 \pm 0.68^{* * *}$ & $2.58 \pm 0.94^{*}$ & 66.67 & 7.13 & 37.27 \\
Aqueous (200mg/kg p.o) & $1.5 \pm 0.43^{* * *}$ & $1.83 \pm 0.48^{* * *}$ & 83.33 & 8.67 & 23.70 \\
Hexane (200mg/kg p.o) & $2.83 \pm 0.95^{* * *}$ & $2.50 \pm 1.01^{* *}$ & 66.67 & 7.20 & 36.61 \\
Chloroform (200mg/kg p.o) & $0.83 \pm 0.31^{* * *}$ & $0.83 \pm 0.31^{* * *}$ & 66.67 & 6.83 & 39.84 \\
Ethyl acetate (200mg/kg p.o) & $2.00 \pm 0.58^{* * *}$ & $3.17 \pm 0.84^{\mathrm{ns}}$ & 83.33 & 8.85 & 22.09 \\
Butanol (200mg/kg p.o) & $2.83 \pm 0.83^{* * *}$ & $2.33 \pm 0.81^{* *}$ & 83.33 & 8.85 & 22.09 \\
\hline
\end{tabular}

Results are shown as Mean \pm SEM. Significant at $\mathrm{P}<0.05, \mathrm{P}<0.01, \mathrm{P}<0.001$, ns $=$ not significant as compared to ethanol

Table 5. Gastric juice parameters in ethanol induced acute gastric ulcer. (3.9 \pm 0.1$)(98.1 \pm 3.8)$.

\begin{tabular}{|c|c|c|c|c|c|}
\hline Group name & $\begin{array}{c}\text { Gastric } \\
\text { volume }(\mathrm{ml})\end{array}$ & pH & $\begin{array}{l}\text { Total acidity } \\
(\mathrm{mEq} / \mathrm{L})\end{array}$ & $\begin{array}{l}\text { Mucous content } \\
\text { ( } \mu \text { g of alcian blue/ } \\
\text { g wet tissue) }\end{array}$ & $\begin{array}{l}\text { Protein } \\
\text { content } \\
(\mu \mathrm{g} / \mathrm{ml}) \\
\end{array}$ \\
\hline Normal (10ml/kg p.o) & $1.35 \pm 0.06^{* * *}$ & $4.00 \pm 0.11^{*}$ & $28.33 \pm 2.03^{* * *}$ & $464.00 \pm 19.85^{* *}$ & $55.67 \pm 4.46^{* * *}$ \\
\hline Ethanol (10ml/kg p.o) & $3.95 \pm 0.15$ & $2.45 \pm 0.17$ & $98.17 \pm 3.82$ & $371.83 \pm 10.23$ & $16.25 \pm 3.21$ \\
\hline Ranitidine $(50 \mathrm{mg} / \mathrm{kg}$ p.o) & $2.13 \pm 0.23^{* * *}$ & $5.77 \pm 0.39^{* * *}$ & $38.17 \pm 2.95^{* * *}$ & $439.00 \pm 11.95^{*}$ & $39.17 \pm 3.62^{* *}$ \\
\hline Omeprazole (20mg/kg p.o) & $\begin{array}{l}1.80 \pm \\
0.29^{* * *}\end{array}$ & $5.96 \pm 0.49^{* * *}$ & $32.33 \pm 2.80^{* * *}$ & $454.33 \pm 14.16^{* *}$ & $34.67 \pm 4.73^{\text {ns }}$ \\
\hline Sucralfat & $1.77 \pm 0.20^{* * *}$ & $5.45 \pm 0.33^{* * *}$ & $39.17 \pm 3.44^{* * *}$ & $432.67 \pm 14.87^{\mathrm{ns}}$ & $39.67 \pm 3.31^{* *}$ \\
\hline Methanol (500mg/kg p.o) & $2.52 \pm 0.34^{* * *}$ & & $48.33 \pm 3.62^{* * *}$ & $468.33 \pm 23.58^{* * *}$ & $28.58 \pm 3.88^{*}$ \\
\hline Aqueous (200mg/kg p.o) & $2.02 \pm 0.19^{* * *}$ & $5.02 \pm 0.31^{* * *}$ & $50.92 \pm 4.75^{* * *}$ & $516.17 \pm 23.96^{* * *}$ & $28.17 \pm 4.14^{\mathrm{ns}}$ \\
\hline Hexane $(200 \mathrm{mg} / \mathrm{kg}$ p.o $)$ & $2.00 \pm 0.25^{* * *}$ & $5.03 \pm 0.30^{* * *}$ & $54.42 \pm 10.34^{* * *}$ & $443.17 \pm 11.12^{*}$ & $30.67 \pm 4.13^{*}$ \\
\hline Chloroform (200mg/kg p.o) & $1.87 \pm 0.21^{* * *}$ & $5.10 \pm 0.37^{* * *}$ & $45.5 \pm 5.96^{* * *}$ & $478.33 \pm 12.78^{* * *}$ & $26.17 \pm 4.15^{* *}$ \\
\hline Ethyl acetate $(200 \mathrm{mg} / \mathrm{kg}$ p.o $)$ & $2.85 \pm 0.26^{*}$ & $4.88 \pm 0.30^{* * *}$ & $58.00 \pm 7.59^{* * *}$ & $443.00 \pm 14.10^{*}$ & $25.83 \pm 4.38^{\mathrm{ns}}$ \\
\hline Butanol (200mg/kg p.o) & $2.61 \pm 0.26^{* *}$ & $5.00 \pm 0.34^{* * *}$ & $60.5 \pm 8.18^{* * *}$ & $414.50 \pm 10.78^{\mathrm{ns}}$ & $23.33 \pm 4.03^{\mathrm{ns}}$ \\
\hline
\end{tabular}

Results are shown as Mean \pm SEM. Significant at $\mathrm{P}<0.05, \mathrm{P}<0.01, \mathrm{P}<0.001$, ns $=$ not significant as compared to ethanol

Macroscopic examination: With the help of magnifying glass, all stomach examined for measurement of ulcer index, streak, spot, hemorrhage and lesions in all treated groups, results given in Figure 3. 
A)

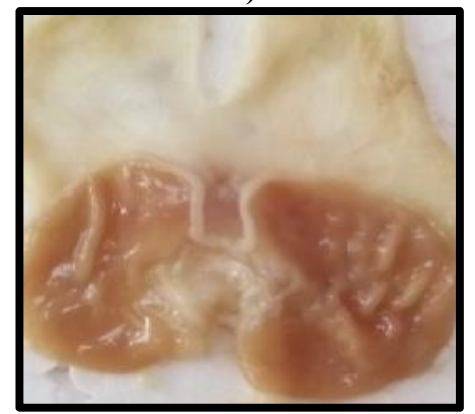

D)

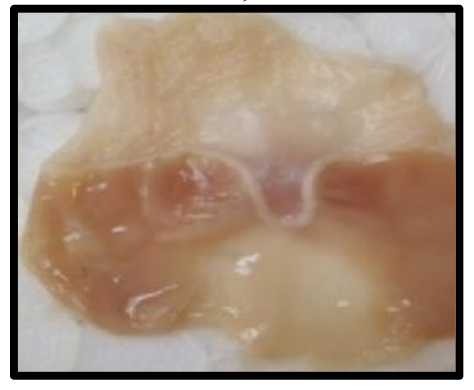

G)

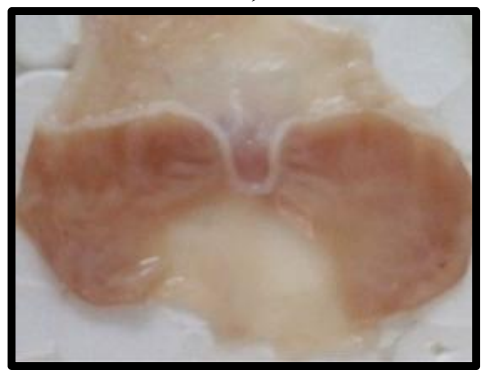

J)

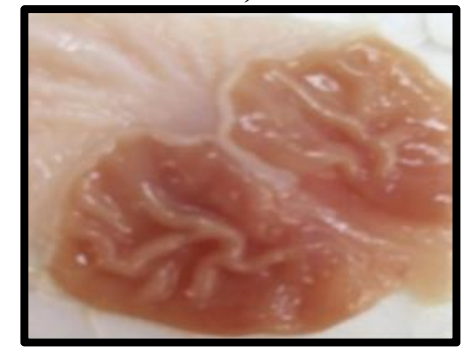

B)

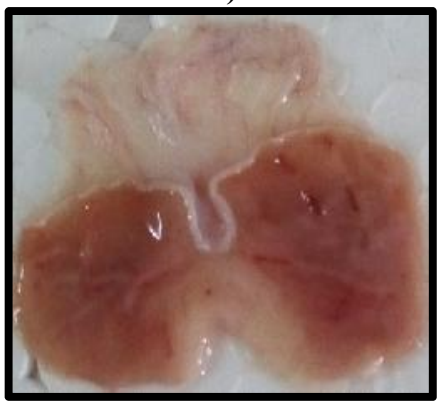

E)

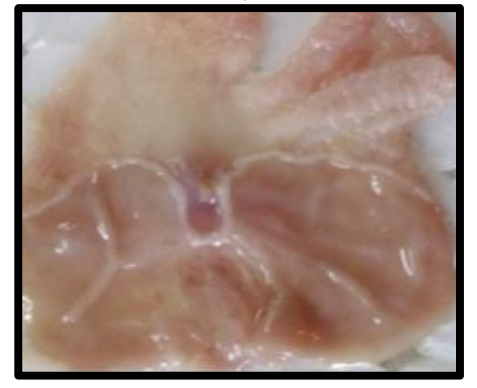

H)

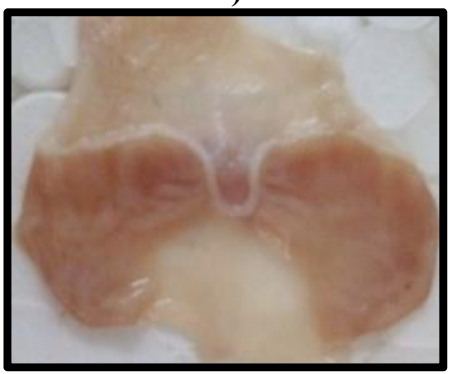

K)

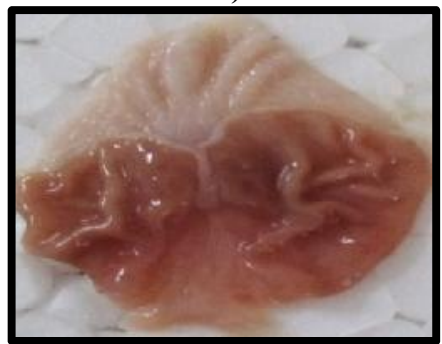

C)

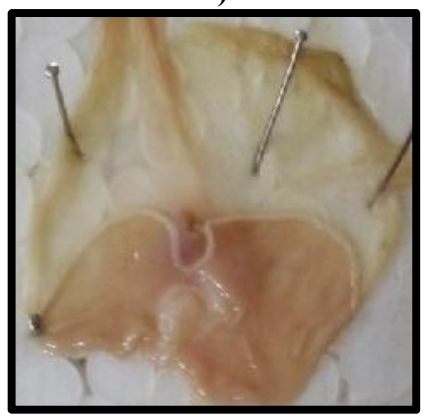

F)

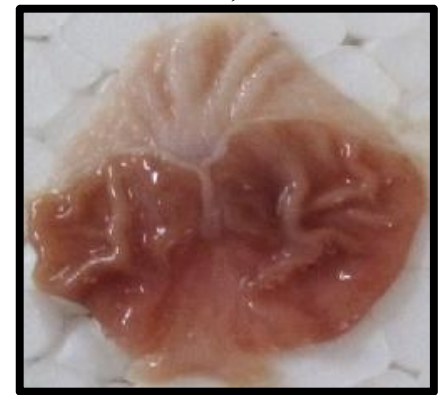

I)

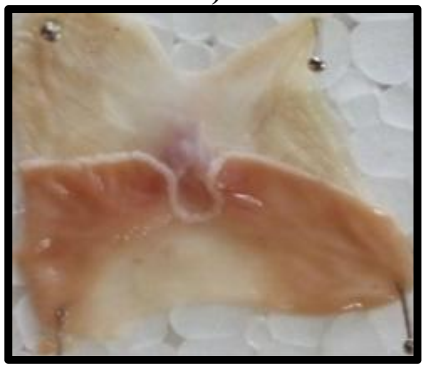

Figure 3. Macroscopic examination of stomachs in different groups e.g., A) Normal, B) Ethanol, C) Ranitidine, D) Omeprazole, E) Sucralfate, F) Methanolic, G) Aqueous, H) n-Hexane, I) Chloroform, J) Ethyl Acetate, K) Butanol.

Histopathological studies: Histological section of gastric mucosa in a rat pre-treated with standard drugs in figure 4. There is mild disruption to the surface epithelium with mild edema and leucocytes infiltration of the submucosal layer. Histological section of gastric mucosa in a rat pretreated with chloroform extract figure 5. There is little disruption to the surface epithelium with no edema and no leucocytes infiltration of the submucosal layer. 
Normal

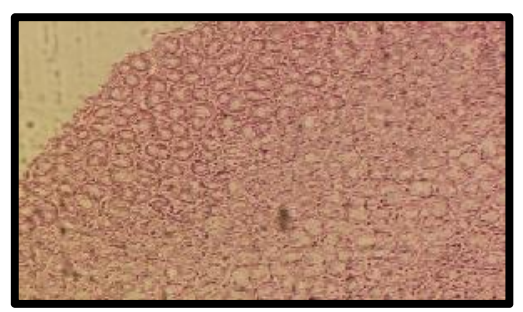

Omeprazole
Ethanol

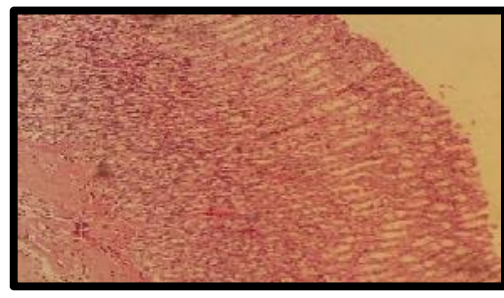

Sucralfate
Ranatidine

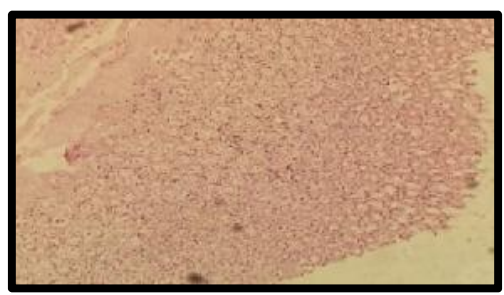

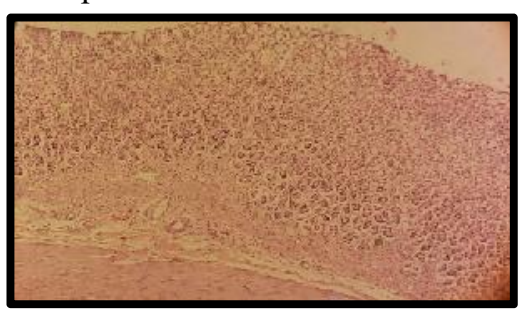

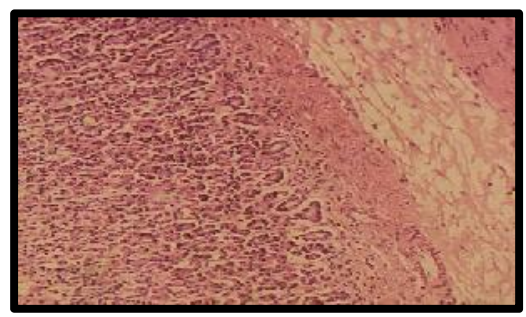

Figure 4. Sections stained with hematoxylin and eosin $(\mathrm{H} \& \mathrm{E})$ displaying the regenerated glandular epithelium was examined by using microscope (Labomed, USA) at magnification 10X.

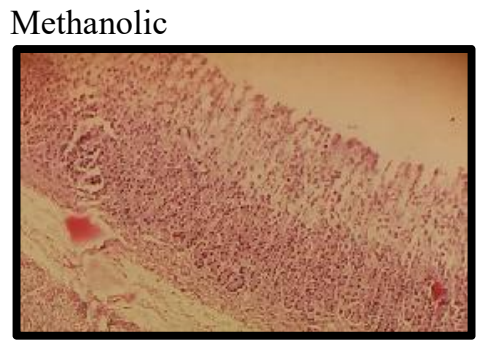

Chloroform

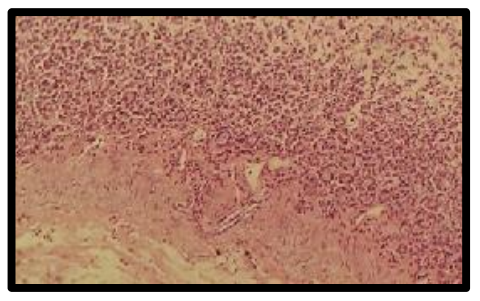

Aqueous

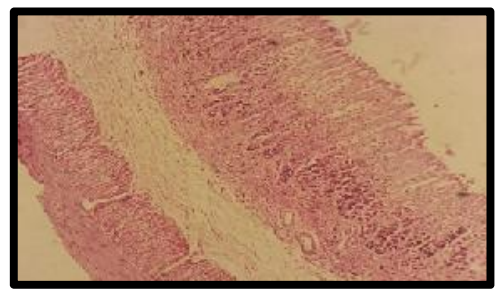

Ethyl acetate

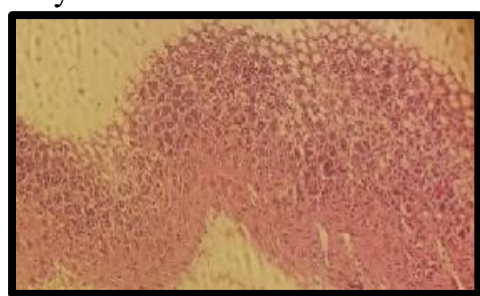

n-hexane

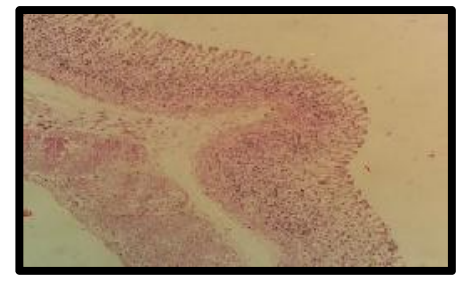

Butanol

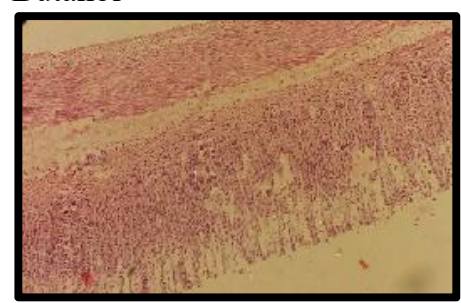

Figure 5. Sections stained with hematoxylin and eosin $(\mathrm{H} \& \mathrm{E})$ displaying the regenerated glandular epithelium was examined by using microscope (Labomed, USA) at magnification 10X.

\section{DISCUSSION}

Nature is ultimate source of human health so we can say that human being entirely depends upon the natural resources to fulfill their daily requirements (Kokoska et al., 2019). For this purpose, demand of medicinal plants and phytochemicals is increased by overcoming the increasing demand of comfort and beneficial needs of the society (Elshafie and Camele, 2017). In this study we evaluate the anthelmintic, insecticidal and antiulcer activity of a natural herb found in Punjab region of Pakistan (Akhtar et al., 2019). The preliminary phytochemical screening of $M$. orontium L are shown in
Table 1. The extract showed the presence of polyphenolic compounds, saponins, flavonoids and alkaloids.

The emergence of resistance to anthelmintic drugs among helminth parasites has become a worldwide phenomenon (Jackson and Coop, 2000). A number of medicinal plants have been shown to possess anthelmintic activity against gastrointestinal parasites (Iqbal et al., 2001; Alawa et al., 2003; Chandrawathani et al., 2006; Swarnkar et al., 2008). In the present study all the extracts showed activity against the parasite at a low concentration i.e., $25 \mathrm{mg} / \mathrm{ml}$. The results were comparable to the anthelmintic drug Albendazole used as standard which killed all the parasites (100\% anthelmintic activity). The crude methanol extract showed $100 \%$ anthelmintic effect 
after $2 \mathrm{hrs}$ of exposure. While the ethyl acetate extract and n-butanol fraction showed $100 \%$ inhibition after less than 2 hrs. Since the extracts are a mixture of thousands of molecules, the extracts could be a source of anthelmintics. Many plant phenolics such as tannins and flavonoids are known to possess anthelmintic activity (Anthnasiadou et al., 2001; da Silva et al., 2008). These compounds kill the parasite by inhibiting ATP synthesis and by binding with the cuticle of the organism making it immobile leading to paralysis and ultimately death of the organism (Martin, 1997; Thompson \& Geary, 1995). The difference in anthelmintic activity of different plant extracts may also be due the difference in total phenolic and flavonoid contents in these extracts. Since the polar fractions contained a high phenolic and flavonoid content than the non-polar fractions this may explain the observed difference in the anthelmintic activity of these extracts.

Treatment groups 6-11 in ethanol induced ulcer model showed significant $(p<0.001)$ anti-ulcer effect. All fractions showed \%age of ulcer inhibition which is comparable to the effect of standard drugs. Histopathological analysis of gastric mucosa of all the extract treated groups showed anti-ulcer effect by giving mild disruption, edema, leucocytes infiltration in submucosal layer of stomach. This might be due to chemical constituents that were extracted in methanol as well as in other fractions. Gul et al., (2015) explored antiulcer activity of Menthe longifolia and found decline in ulcer index (Gul et al., 2015). Dalbergia sissoo has been discovered to possess anti-ulcer activity by gastric mucosal protection (Gul et al., 2016). Our results are in accordance with the findings of studies conducted by Gul et al., 2015 and 2016. Banerjee and Firdous, (2015) studied Ipomoea staphylina hydroalcoholic extract for anti-ulcer activity to find out new anti-ulcer drug with less adverse effects as compared to currently available ulcer treatment medicines. This plant extract showed significant decrease in total acidity, ulcer index and increase in mucus and protein content which was supported by histopathological analysis. Current results are in agreement with Banerjee and Firdous findings (Banerjee and Firdous; 2015). Increased gastric juice secretion and decreased gastric $\mathrm{pH}$ lead to increase in acidity in stomach which if not treated at early stage may cause gastric ulceration. M. orontium extracts showed anti-ulcer activity by decreasing lesions score, reducing gastric juice volume and acidity and increasing gastric $\mathrm{pH}$.

Acknowledgment: The authors gratefully appreciate the financial support by the faculty of Punjab University College of Pharmacy, University of the Punjab. Lahore, Pakistan.

\section{REFERENCES}

Ajaiyeoba, E.O., P.A. Onocha, and O.T. Olarenwaju (2001). In vitro anthelmintic properties of Buchholzia coriaceae and Gynandropsis gynandra extracts. Pharm. Biol. 39(3): 217-220.

Akhtar, M.F., A. Saleem, and M. Saleem (2019). A Comprehensive Review on Ethnomedicinal, Pharmacological and Phytochemical Basis of Anticancer Medicinal Plants of Pakistan. Curr Cancer Drug Targets. 19(2): 120-151.

Alphin, R.S. and J.W. Ward (1967). Actions of hexopyrronium bromide on gastric secretion in dogs and on gastric secretion and ulceration in rats. Arch. Int. Pharmacodyn. Ther. 168(1): 82100.

Alawa, C.B.I., A.M. Adamu, J.O. Gefu, O.J. Ajanusi, P.A. Abdu, N.P. Chiezey, J.N. Alawa and D.D. Bowman (2003). In vitro screening of two Nigerian medicinal plants (Vernonia amygdalina and Annona senegalensis) for anthelmintic activity. Vet. Parasitol. 113: 73-81.

Anthnasiadou, S., I. Kyriazakis, F. Jackson and R.L. Coop (2000). Direct anthelmintic effects of condensed tannins towards different gastrointestinal nematodes of sheep: In vitro and in vivo studies. Vet. Parasitol., 99: 205-219.

Balmik, M., G. Dubey, S.K. Ghauary, and P.K. Jain (2019). Phytochemical Screening and Evaluation of Antiulcer Activity of Hydroalcoholic Extract of Lilium Candidum Flowers. J Drug Deliv Sci Technol. 9(4-A): 646-650.

Banerjee, A., Firdous, S. M (2015). Antiulcer activity of hydroalcoholic extract of Ipomoea staphylina plant in rats. Bangladesh J Pharmacol. 10: 65253.

Bohm, B.A. and M.R. Koupai-Abyazani (1994). Flavonoids and condensed tannins from leaves of Hawaiian Vaccinium reticulatum and $V$. calycinum (Ericaceae). Pacific Sci. 48: 458-463.

Boligon, A.A., M.M. Machado, and M.L. Athayde (2014). Technical evaluation of antioxidant activity. Med chem. 4(7): 517-522.

Bundy, D. A. P (1994). 1. Immunoepidemiology of intestinal helminthic infection: The global burden of intestinal nematode disease. Trans Royal Soc Trop Med Hyg. 8: 259-261.

Bruneton, J (1955). Pharmacognosy, phytochemistry, Medicinal plants. France: Lavoisiler publishing co. 265-380.

Chandrawathani, P., K.W. Chang, R. Nurulaini, P.J. Waller, M. Adnan, C.M. Zaini, O. Jamnah, S. Khadijah and N. Vincent (2006). Daily feeding of fresh neem leaves (Azadirachta indica) for worm control in sheep. Trop. Biomed., 23(1): 23-30. 
Choudhary, M.I. and W.J. Thomsen (2001). Bioassay techniques for drug development. The Netherlands: Harward Academic Publisher. 6768.

Coles, G.C., F. Jackson, W.E. Pomroy, R.K. Prichard,H.G. Samson, M.A. Taylor, and J. Vercruysse (2006). The detection of anthelmintic resistence in nematodes of veterinary importance. Vet. Parasitol. 136: 167-185.

da Silva, V.C., M.G. de Carvalho and H.R. Borba (2008). Anthelmintic activity of flavonoids isolated from roots of Andira anthelmia (Leguminosae). Rev. Bras. Farmacogn., 18(4): 573-576.

Ejikeme, C., C.S. Ezeonu and A.N. Eboatu (2014). Determination of Physical and Phytochemical Constituents of some Tropical Timbers Indigenous to nigerdelta area of nigeria. Eur Sci J. 10(18): 247-270.

Elshafie, H.S. and I. Camele (2017). An overview of the biological effects of some mediterranean essential oils on human health. Biomed Res Int. 2017.

Garber, A. and S. Jang (2016). Novel therapeutic strategies in the management of non-variceal upper gastrointestinal bleeding. Clin. Endosc. 49(5): 421.

Guideline Document on Acute oral Toxicity Testing, Series on Testing and Assessment No. 423. Paris: Organization for Economic Co-Operation and Development, OECD Environment, Health and Safety Publications (1996).

Gul, H. Saleem, U. and B. Ahmad (2016). Does Dalbergia sissoo leaves possess anti-ulcer activity: An experimental study in alcohol and aspirin induced ulcerative rat models. Bangladesh J Pharmacol. 2: 100-04.

Gul, H. Abbas, K. and M. I. Qadir (2015). Gastroprotective effect of ethanolic extract of Mentha longifolia in alcohol- and aspirin-induced gastric ulcer models. Bangladesh J Pharmacol. 10: 24145

Hollander, D., A. Tarnawski, W.J. Krause, and H. Gergely (1985). Protective effect of sucralfate against alcohol-induced gastric mucosal injury in the rat: macroscopic, histologic, ultrastructural, and functional time sequence analysis. Gastroenterology. 88(1): 366-374.

Iqbal, Z., Q.K. Nadeem, M.N. Khan, M.S. Akhtar and F.N. Waraich (2001). In vitro anthelmintic activity of Allium sativum, Zingiber officinale, Curcurbita mexicana and Ficus religiosa. Int. J. Agric. Biol., 3(4): 454-457.

Ishtiaq, S., T. Ali, B. Ahmad, F. Anwar, M.S.K. Afridi, and H. Shaheen (2017). Phytochemical and biological evaluations of methanolic extract of
Amaranthus graecizans subsp. silvestris (Vill.) Brenan. Brit J Pharmaceut Res. 15(3): 1-11.

Jabeen, A., M. A. Khan, M. Ahmad, M. Zafar, and F. Ahmad (2009). Indigenous uses of economically important flora of Margallah hills national park, Islamabad, Pakistan. Afr. J. Biotechnol. 8(5): 763-784.

Jackson, F. and R.L. Coop, 2000. Development of anthelmintic resistance in sheep nematodes. Parasitol., 20: 95-107.

Javed, A., M. Usman, S.M. Haider, B. Zafar, and K. Iftikhar (2019). Potential of Indigenous Plants for Skin Healing and Care. Am. Sci. Res. J. Eng., Technol., Sci. 51(1): 192-211.

Kamran, S., H. Karimian, N. Salehen, A. Khalajhedayati, B.A. Razak, and N.A. Majid (2019). Acute Toxicity and Gastroprotective Effect of 2pentadecanone in Ethanol-induced Gastric Mucosal Ulceration in Rats. Pharmacology, 15(8): 944-952.

Khan, W., R. A. Khan, Ahmed, M. Khan, L.U. and Khan, M. A (2016). Pharmacological evaluation of methanol extracts of Cyperus scariosus. Bangla. J. Pharmacol. 11: 353-58.

Kokoska, L., P. Kloucek, O. Leuner, and P. Novy (2019). Plant-derived products as antibacterial and antifungal agents in human health care. Curr Med Chem. 26(29): 5501-5541.

Liaudanskas, M., K. Zymonè, J. Viškelis, A. Klevinskas, and V. Janulis (2017). Determination of the phenolic composition and antioxidant activity of pear extracts. J. Chem. 24-26.

Lönnig, W. E., K. Stüber, H. Saedler, and J. H. Kim (2007). Biodiversity and Dollo's Law: To What Extent can the Phenotypic Differences Between Misopates orontium and Antirrhinum majus be Bridged by Mutagenesis? Biorem. Biodiv and Bioavail. 1: 1-30.

Lowry, O.H., N.J. Rosebrough, A.L. Farr and R.J. Randall (1951). Protein measurement with the Folin phenol reagent. J. biol. Chem. 193: 265-275.

Magaji, M.G., A.H. Yaro, A. Mohammed, A.U. Zezi, Y. Tanko, and T.Y. Bala (2007). Preliminary antidiarrhoeal activity of methanolic extracts of Securinega virosa (Euphorbiaceae). Afr. J. Biotechnol. 6(24).

Martin R.J (1997). Mode of action of anthelmintic drugs. Vet. J. 154:11-34.

Mizui, T., H. Sato, F. Hirose, and M. Doteuchi (1987). Effect of antiperoxidative drugs on gastric damage induced by ethanol in rats. Life Sci. 41(6): 755-763.

Navarrete, A., L.S. Martínez-Uribe, and B. Reyes (1998). Gastroprotective activity of the stem bark of Amphipterygium adstringens in rats. Phytother Res. 12: 1-4. 
Prabhu, V. and A. Shivani (2014). An overview of history, pathogenesis and treatment of perforated peptic ulcer disease with evaluation of prognostic scoring in adults. Ann Med Health Sci Res. 4(1): 22-29

Ramakrishnan, K. and R.C. Salinas (2007). Peptic ulcer disease. Am Fam Physician. 76(7): 1005-1012.

Rababah T.M, E.L. Rice, W.S.Hettiarachy and R. Horax. (2004). Total phenolics and antioxidant activities of fenugreek, green tea, black tea, grap seed, ginger, rosemary, gotu, kola, ginkgo extracts, vitamin E, and terbutyl hydroquinone. J. Agric. Food Chem. 52: 5183-5186.

Riaz, M., M. Zahid, M.A. Sherkheli, M. Altaf, S. Manzoor, N. Abbasi, R. Rashid, M.Q. Khan, and S. Andleeb (2019). Measurements of metal contamination, antimicrobial and antioxidant activities of five medicinal herbs from Azad Kashmir. Bangladesh pharm j. 22(1): 7-12.

Riaz, M., N. Rasool, S. Rasool, U. Rashid, I.H. Bukhari, M. Zubair, M. Noreen, and M. Abbas (2013). Chemical analysis, cytotoxicity and antimicrobial studies by snapdragon: A medicinal plant. Asian J. Chem. 25(10): 5479.

Sahreen S, R.A.Khan and M.R. Khan (2015). Evaluation of phytochemical content, antimicrobial, cytotoxic and antitumor activities of extract from Rumex hastatus D. Don roots. BMC Compl. Alter. Med. 15:211; DOI 10.1186/s12906-0150736-y.

Sahreen S, M.R. Khan and R.A. Khan (2014). Estimation of flavoniods, antimicrobial, antitumor and anticancer activity of Carissa opaca fruits. BMC Compl. Alter. Med. 13:372.
Shay, H., (1945). A simple method for the uniform production of gastric ulceration in the rat. Gastroenterology, 5: 43-45.

Sondhi, S.M., M. Johar, N. Singhal, S.G. Dastidar, R. Shukla, and R. Raghubir (2000). Synthesis and anticancer, antiinflammatory, and analgesic activity evaluation of some sulfa drug and acridine derivatives. Monatshefte für Chemie/Chemical Monthly. 131(5): 511-520.

Swarnkar, C.P., D. Singh, F.A. Khan and P.S.K. Bhagwan (2008). Potential of alcoholic extract of Azadirachta indica bark as anthelmintic in sheep. J. Vet. Parasitol., 22(2): 13-16.

Tagboto, S. and S. Townson (2001). Antiparasitic properties of medicinal plants and other naturally occurring products. Advances in parasitology. 50: 199-295.

Tanih, N.F., M. McMillan, N. Naidoo, L.M. Ndip, L.T. Weaver, and R.N. Ndip (2010). Prevalence of Helicobacter pylori vacA, cagA and iceA genotypes in South African patients with upper gastrointestinal diseases. Acta tropica. 116(1): 68-73.

Thompson, D.P. and T.G. Geary (1995). The structure and function of helminth surfaces. In: Biochemistry and molecular biology of parasites, 1st ed. Academic press, New York, pp. 203- 232.

Tripathi, K.P., (2003). Essentials of meditional pharmacology. 5th Ed. Jaypee Brothers Medical Publishers (P) LTD; New Delhi (India). 759 p

Zangeneh, M.M., S. Salmani, A. Zangeneh, E. Bahrami, and M. Almasi (2019). Antiulcer activity of aqueous extract of leaves of Mentha piperita in Wistar rats. Comp Clin Path. 28(2): 411-418. 